\title{
Evidence-informed teaching and practice-informed research
}

\author{
Leila E. Ferguson ๑ \\ School of Health Sciences, Kristiania University College, Oslo, Norway
}

\begin{abstract}
In this commentary, I seek to join the ongoing conversation about evidence-informed educational practice that has been threaded through this special issue. I do so by drawing on related insights from the fields of teachers' beliefs and epistemic cognition and considering the roles of teacher education and educational research in improving (preservice) teachers' use of educational research. In particular, I focus on the merits of explicit research-based practice in teacher educators' teaching and ways that they can encourage preservice teachers' interactions with educational research in class, and methods of changing the beliefs that may underlie (preservice) teachers' engagement with educational research evidence, and finally, the need for clearly communicated research, including details of implementation.
\end{abstract}

Keywords: Evidence-informed teaching, teachers' beliefs, sourcing, teachers' epistemic cognition

Evidenzinformiertes Lehren und Praxisinformierte Forschung

Zusammenfassung: Mit diesem Kommentar möchte ich zur Diskussion über eine evidenzbasierte Bildungspraxis beitragen, die sich wie ein roter Faden durch dieses Themenheft zieht. Ich tue dies, indem ich auf verwandte Erkenntnisse aus der Forschung zu Überzeugungen von Lehrkräften sowie zu epistemischen Kognitionen zurückgreife, und die Rolle der Lehrerbildung und der Bildungsforschung bei der Verbesserung der Nutzung von Forschungserkenntnissen durch (angehende) Lehrkräfte betrachte. Insbesondere konzentriere ich mich auf die Vorzüge, die eine explizit forschungsbasierte Praxis in der Lehre von Lehrerbildnern und Lehrerbildnerinnen haben kann; auf die Möglichkeiten, wie Lehrerbildner und Lehrerbildnerinnen die Interaktion von (angehenden) Lehrkräften mit Bildungsforschung im Unterricht fördern können; auf Methoden zur Veränderung von Überzeugungen, die der Auseinandersetzung mit bildungswissenschaftlicher Evidenz durch angehende Lehrkräfte zugrunde liegen können; und schließlich auf die Notwendigkeit, Forschung klar zu kommunizieren, einschließlich Einzelheiten zu deren Umsetzung.

Schlüsselwörter: Evidenzinformiertes Lehren, Überzeugungen von Lehrkräften, Sourcing, Epistemische Kognitionen von Lehrkräften

If 'good teaching' came in bottles, what would the list of ingredients look like and how would producers come to know the best recipe? And if your job was to satisfy 30 thirsty youngsters under watchful eyes, would you be inclined to rely on your favourite grandparent's tried and tested recipe? A recipe that you have been watching them make since you were five years old, and gradually taking responsibility for making for about the last four years. Or would you seek out experts' suggested approaches and give them supremacy over your personal experience? What then, if you went for the trusty recipe and found out that it did not suit the palate of all your students, even causing some to react in unexpected ways? Would you turn to an experienced friend for advice, do a quick google search and check an easily accessible forum, or might you be inclined to stop up, search for and identify relevant research, and then reflect on what the literature has to say and how this might be relevant for your own situation?

'Good teaching' is far more complex than home brewing. However, it too comes in several different flavours that must be adapted to groups of students, with specific needs, knowledge, and interests, as well as occurring in complex and varying contexts. There are multiple sources of teaching knowledge, and it is likely that competent teachers use these sources in combination (Shulman, 1987; Ulvik, Riese \& Roness, 2018). Partly in reaction to research-based conceptualisations of 'good teaching' at that time, Lee Shulman (1987) identified four main sources of teaching knowledge, of which, one has a focus on research evidence: "(1) scholarship in the content disciplines, (2) the materials and settings of the institutionalized educational process (for example, curricula, textbooks, school organizations and finance, and the structure of the teaching profession), (3) research on schooling, social organizations, human learning and development, and the other social and cultural phenomena that affect what teachers can do, and (4) the wisdom of the practice itself" (p.8, my emphasis). Nowadays, there is also a drive from several holds, to increase (preservice) teachers' evidence-based practice (e.g., European Commission, 2007; Norwegian Ministry of Education and Research, 2014). The collected papers in this special issue shine light on the problem-space around evidence-based 
practice in education from diverse angles, with a particular focus on (preservice) teachers' beliefs about and use of evidence, or sources of teaching knowledge.

I am especially glad that this group of insightful researchers have come together in this special issue, during a time when teachers worldwide are being forced to develop their practice in multiple ways, and when they may not have the time or resources to ground their decisions in research evidence (i.e., during the COVID-19 pandemic that has caused temporary school closures and necessitated online/distance learning around the globe). I endeavour to springboard from their findings and conclusions, from the perspective of an educational researcher with an interest in (preservice) teachers' (epistemic) beliefs, including beliefs about sources of teaching knowledge, and how these (can) develop over time. I view these beliefs as important for teachers' own learning and professional development, as well as the learning of their students (Buehl \& Fives, 2016; Lunn Brownlee, Ferguson \& Ryan, 2017). I will focus on the roles of teacher education and educational researchers in the current quest to increase evidence-based educational practice.

\section{Evidence-based practice in education}

Evidence-based practice may be viewed as teachers' tendency, "to ground their decisions and the way they handle pedagogical problems on scientific evidence" (Csanadi, Kollar \& Fischer, 2021, p.2). In general terms, 'evidence' is a necessary element that strengthens one's "case for holding a particular belief as true" (Biesta, 2010, p.493), or gives grounds to act in a certain way (Kvernbekk, 2016). It is a function of knowledge and reasoning (Kvernbekk, 2016), and thus epistemic in nature. In terms of teaching, 'evidence' presently tends to refer to educational research and theories. Yet it should also be noted that 'evidence' is wider than 'scientific', and may expand beyond truth (Biesta, 2010), rendering some forms of evidence as better than others. Attempts at ranking different forms of evidence are, for example, based on trustworthiness. One example is Pawson's (2006) 'hierarchy of evidence,' regarding the ranking of forms of evidence in meta-analytic studies. Randomised controlled trials are followed in descending order by quasi-experimental studies, pre-post comparisons, cross-sectional studies, evaluations of processes, such as action research, case studies, descriptive studies, professional or expert testimonies and, finally, user opinions. However, while randomised controlled trials may provide the best type of evidence for causal claims, it is important to remember that educational practice is more than a set of interventions, and may therefore require professional judgements based on different kinds of evidence that fit specific (practical) needs, or what Kvernbekk terms a "bouquet of evidence" (2016, p.20).

'Based', and 'informed', have to do with the role of evidence for one's professional practice, with a central question being whether evidence should form the sole basis for one's decisions (Snow, 2019). From a medical point of view, practitioners engage in practices that "integrate best available external evidence with their individual professional practice and experience to meet their clients' needs" (Hartmann, Kindlinger \& Trempler, 2021, p.3). Applied to education, teachers should not be expected to base every single decision on educational research, but to engage their professional judgement where necessary and sufficient and refer to evidence as a type of backing (Kvernbekk, 2016). Consequently, I prefer to use 'evidence-informed practice', or even 'evidence and expertise-based practice' (see Snow, 2019), where evidence makes up one of several important sources for informing a professional teacher's practice (Diery, Vogel, Knogler \& Seidel, 2020), though I also refer to evidence-based practice throughout this commentary.

Professional teachers weigh different sources of evidence in light of their domain expertise and contextual factors within the frame of local and national policies and interventions to meet educational problems and continue to update and expand their knowledge base (Bubikova-Moan \& Opheim, 2021; Diery et al., 2020; Hartmann et al., 2021; Menz, Spinath \& Seifried, 2021; Thomm, Seifried \& Bauer, 2021). Such an understanding of evidence-based practice does not exclude teachers' experience or 'wisdom of practice' (Shulman, 1987), nor the beliefs that teachers hold based on anecdotal evidence (Kiemer \& Kollar; 2021; Menz et al., 2021), nor does it preclude the act of gaining knowledge via the testimony of colleagues. However, some of these beliefs will be false (misconceptions, Menz et al., 2021) and may prove difficult to revise, even in the face of conflicting evidence (Chinn \& Brewer, 2000). Further, use of informal sources of knowledge should, ideally, be outweighed by consulting research evidence since reliance on anecdotal evidence over scientific evidence might lead to problematic outcomes such as educational misconceptions continuing to flourish if they are not addressed (see Menz et al., 2021).

The relation between different sources of teaching knowledge and teachers' preconceptions and sourcing is addressed by literature on teacher beliefs and (teachers') epistemic cognition (e.g., Bråten \& Ferguson, 2015; Buehl \& Fives, 2009, 2016; Chinn, Buckland \& Samarapungavan, 2011; Chinn \& Rinehart, 2016; Feucht, Lunn Brownlee \& Schraw 2017; Hartmann et al., 2021). In this discussion, I seek to contribute to the literature on evidence-informed 
educational practice by drawing on insights on teachers' beliefs and epistemic cognition. A critical assumption to my approach is that there is a relation between teachers' beliefs, epistemic cognition, and (evidence-informed) practice (Buehl \& Beck, 2015; Buehl \& Fives, 2016).

\section{(Preservice) Teachers' beliefs about teaching knowledge}

Teachers' beliefs are suppositions held by (preservice) teachers that have relevance for their professional development and practice (Ferguson \& Lunn Brownlee, 2021). As a result of experience as students in classrooms over many years, the beliefs or (mis)conceptions that (preservice) teachers hold may be deeply-rooted, connected to other belief systems (Lortie, 1975; Rokeach, 1968), and central for their understanding of teaching and learning. Researchers have identified a plethora of beliefs in teachers concerning, for example, students and how they learn, teaching form, teaching ability, and teaching knowledge, including sources of knowledge (Fives \& Gill, 2015). Most salient for this discussion are the beliefs that (preservice) teachers hold about valid sources of teaching knowledge and beliefs about the justification of knowledge claims. The burgeoning literature addressing teachers' epistemic beliefs sits at the meeting point of research addressing teachers' beliefs and epistemic cognition, respectively (e.g., Bråten \& Ferguson, 2015; Brownlee, Purdie, \& Boulton-Lewis, 2001; Brownlee, Schraw \& Berthelsen, 2011; Buehl \& Fives, 2009, 2016; Gill, Ashton \& Algina, 2004; Olafson \& Schraw, 2006).

Epistemic cognition concerns matters relating to truth and knowledge, and questions like 'how do I know this?' and 'can I rely on this source of information to provide me with true beliefs?'. It "represents learners' thinking about the epistemic characteristics of specific information, knowledge claims, and their source as well as engaging in reasoning about the elements mentioned above" (Lee, 2021, p.1). These are salient questions for professional teachers in terms of their own knowledge, and that of their students (Buehl \& Fives, 2016).

Individuals' views of knowledge and knowing are generally considered to develop during the course of a lifetime, with development arguably gathering most speed during individuals' schooling and during (in)formal learning settings (Perry, 1970). 'Source of knowledge' and 'justification of knowledge claims' have long been central tenets of epistemic cognition (e.g., Kuhn, 1999). For example, Hofer and Pintrich's review of research examining students' epistemic beliefs included the key dimensions focusing on the nature of knowledge (the degree of certainty and simplicity of knowledge) and the nature of knowing (sources of knowledge and justification for knowing; Hofer \& Pintrich, 1997).

Teachers' beliefs about the nature of knowledge, in terms of relative certainty and simplicity, will likely influence the degree to which they consider questions concerning the nature of knowing (how one knows; Chinn et al., 2011). For example, if a teacher believes that knowledge about teaching (let us say 'assessment,' as an example) is certain, then they may believe that little will be added by consulting the research-base about how to assess students' understanding of a biological process (again, as an example) if a colleague already knows the answer, and viewing assessment in terms of certain knowledge may hinder teachers from further inquiry. At the same time, asking a colleague might be an intermediary placeholder, until a time when they have the opportunity for further investigation, which underlines the importance of context in interpreting teachers' beliefs and practice.

In terms of teaching, the source and justification dimensions range from viewing knowledge about teaching as originating outside the self in external authority, to viewing knowledge as constructed by individual teachers in interaction (source of knowledge); and from validating knowledge claims through authority, observation or personal processes, to use of inquiry and evaluation by integrating different sources (justification for knowing; Ferguson, Bråten \& Strømsø, 2012). Recently, (epistemic cognition) researchers have underlined the importance of broadening the scope of sources under consideration, as well as understanding how sources of knowledge are used in interaction, and the context-sensitivity of individuals' reasoning about sources of knowledge (Battersby, 2019; Chinn, et al., 2011). Moreover, the important role of testimony as a reliable process to attain valid knowledge has been underscored in light of its important role in doing so in philosophy and science (Chinn et al., 2011).

Based on a comprehensive review of psychological and philosophical literature, Chinn et al. (2011) categorised sources of knowledge in terms of being gained via (i) senses, (ii) reflection over own experience, (iii) recalling past events and experiences, (iv) the application of logic, and (v) appealing to others, or testimony, that is, "all social forms of sharing information and knowledge with others" (Chinn et al., 2011, p.152), including appeals to scientific sources of knowledge, as well as experts and peers.

In relation to the question of what sources of knowledge teachers tend to engage with, Buehl and Fives (2009) conducted a mixed methods study focusing on American teachers' beliefs about sources of teaching knowledge. The researchers were able to identify six themes relating to teachers' beliefs about formal and informal sources of teaching knowledge, similar to those identified by researchers in the field of teacher education (e.g., Shulman, 1987) 
and epistemic cognition (Chinn et al., 2011). Thus, teacher beliefs about sources of teaching knowledge centred around teacher training and "formalized bodies of information" (Buehl \& Fives, 2009, p.396), and educational experience, as well as "[o]bservational, collaborative, ... enactive experiences [and] self-reflection" (p.397). Bråten and Ferguson (2015) had participants in Norway rate sources of teaching knowledge, reducing the 'grain-size' further to sources such as research literature, observation of other teachers' practice, own experience as a student, as well as social media sources. Although these studies represent important steps to identifying the sources of knowledge that teachers base their practice on, they also lack contextual-sensitivity, and information about what situations teachers called to mind as they answered the questions.

In their study on teacher beliefs about sources of knowledge, Kiemer and Kollar (2021) extend the current knowledge base on teachers' beliefs about sources of knowledge with a focus on so-called utility beliefs, that is, teachers' choice of scientific and non-scientific theories and evidence, in terms of how useful they are for considering given problematic classroom situations, and further study relations between utility beliefs and source selection. They found that rather than research- and theoretically based knowledge, the preservice teachers often employed experiential knowledge sources and intuitive understandings. Further, preservice teachers tended to construe new information in ways that fit prior beliefs, using "pseudo-evidence" to support their interpretations (Kiemer \& Kollar, 2021, p.8). These findings align with previous results in studies focusing on experts and lay-people, such as Chinn and Brewer's (2000) summary of potential knowledge-change in responses to new data. Moreover, they demonstrate the importance of addressing teacher beliefs in teacher education.

Accordingly, an important strand of research on epistemic cognition concerns ways of changing people's views of knowledge and knowing, for example through interventions (Gill et al., 2004; Kerwer \& Rosman, 2020; Kienhues, Bromme \& Stahl, 2008; Sinatra \& Chinn, 2012). Mainly using (multiple-)text-based approaches, researchers have studied the effects of confronting individuals with information that conflicts with their existing views in order to impose doubt on one's existing views of knowledge, and an acceptance of the need to change these views, as well as the will, and ability to do so (Bendixen \& Rule, 2004; Kerwer \& Rosman, 2020). For example, building on insights from the field of conceptual change theory, Gill et al. (2004) had preservice teachers read text that first drew attention to the matter that the text would challenge their existing beliefs (so-called 'augmented activation'), and then did so (using a refutational text). As a result of the short intervention, the researchers documented more advanced beliefs about teaching and learning in participants.
Having preservice teachers explicitly reflect on their existing epistemic beliefs in teacher education is another approach that has been prominent in the research literature (Parkinson \& Maggioni, 2017; Schraw, Olafson \& Vander Veldt, 2011). Expanding on this line of thinking, Lunn Brownlee and colleagues (Feucht et al., 2017; Lunn Brownlee et al., 2017) have argued the merits of reflexivity to promote change in epistemic cognition in the field of teaching. This approach includes explicit reflection on teaching processes in action, for example, in light of epistemic aims for students, with the goal of aligning actions and beliefs as a result of reflexive deliberation that leads to said action, and a new opportunity for reflection (Lunn Brownlee et al., 2017). In their discussion of ways to change students' epistemic cognition, Sinatra and Chinn (2012) reviewed important elements of intervention such as scaffolding, modelling, inquiry and cognitive dissonance. Sinatra and Chinn further recommended "upping the ante" (p.274) by combining especially engaging techniques such as inquiry or argumentation to foster change in particularly deeply held beliefs. This line of thinking is harnessed in the work of Zimmermann and Mayweg-Paus (2021) in their use of reflection and collaborative reasoning to support critical reflection around sourcing.

In sum, teachers seem to trust in, and make use of a variety of formal and informal sources of teaching knowledge, and there is support for doing so in research from teacher education (Shulman, 1987), the philosophy of education (Kvernbekk, 2016) and educational psychology (Chinn et al., 2011). However, given links between trust in anecdotal sources of teaching knowledge and endorsement of educational misconceptions (Menz et al., 2021), and since teachers that frame their activities in terms of own experience, may only be able to see their activities in a limited way, opening up their frame of understanding by discussing experiences in terms of research may be a way forward (Helleve, 2014). This may require more focus on their epistemic cognition and beliefs about sources of knowledge. Unfortunately, however, this knowledge remains little known among teachers (Alexander, 2017; Hofer, 2017). In the next section, I will explore avenues for addressing this disparity.

\section{Evidence-informed practice in education - The roles of teacher education and educational researchers}

In an ever-increasingly complex, uncertain world, parents, and society, crave the best education that teachers and re- 
searchers can provide for coming generations (Biesta, 2010) and while educational research findings often seem intuitively 'correct' and common sense, feelings of knowing and anecdotal-based evidence cannot replace educational expertise. Indeed, educational myths still flourish (de Bruyckere, Kirschner \& Hulshof, 2015), and even teachers hold misconceptions about education that are difficult to resolve with systematic, research-based approaches (Menz et al., 2021). Also, teaching and teacher education face challenges in apprenticeship of observation (Lortie, 1975), and some teachers perceive teaching skills as innate rather than acquired (Buehl \& Fives, 2009).

Teachers have limited time and resources to use on professional development and may be more inclined to rely on non-scientific, intuitively appealing pseudo-evidence, than peer-reviewed, scientifically robust research articles (Hendriks, Seifried \& Menz, 2021; Kiemer \& Kollar, 2021; Thomm, Sälzer, Prenzel \& Bauer, 2021), and this also seems to apply to teacher educators (Diery et al, 2021). Not only is it difficult to see signs of systematic application of educational research, but haphazard attempts to do so are often further hampered by educational policies and trends (Slavin, 2002). Added to all of this is the abundance of information of varying degrees of trustworthiness made accessible by the internet that may be difficult to assess for (preservice) teachers (Zimmermann \& Mayweg-Paus, 2021).

\section{The role of teacher education}

\section{Research-based teacher education}

As a starting point for helping teachers to turn to educational literature as a source of knowledge, I would first like to outline the role of teacher education as an epistemic system in which preservice teachers' appreciation of the utility of educational research, and experiences with applying it may be fostered by university teachers and practice teachers (or mentors) that preservice teachers meet in the course of their education.

(Preservice) teachers' epistemic cognition includes beliefs about reliable evidence and the related epistemic processes engaged in attaining and using it, and is influenced by the context in which it is formed and shall operate (Greene, 2016). Thus, teacher education is an example of an epistemic system that "endorse[s] particular epistemic norms, as well as particular epistemic procedures or practices" (Greene, 2016, p.267). Following this line of thinking, teacher education is an opportunity to help (re-) socialise preservice teachers by shaping their epistemic standards and aims.

Using an online-survey to investigate evidence-based practice in higher education, Diery and colleagues (2020) recently found that although teacher educators were posi- tive towards evidence-based practice and use of empirical evidence in their own teaching, they also lacked time and resources to keep up to date. This not only seems problematic for teacher educators' practice but may contribute to a situation where preservice teachers lack sufficient modelling of evidence-based practice as a result. Preservice teachers not only learn about educational theories and research in educational psychology classes as part of teacher education courses, but they observe (their) teachers, too. To gain insight into teaching they need to be made privy to the beliefs, research, knowledge, and reflections that influence teacher educators' practice (Helleve, 2014). Explicitly research-based teacher education appears to be one way of helping preservice teachers to be socialised into an epistemic system where it is, for example, acceptable to ask about the research-base for practices, and where teacher educators share insights around the evidence-base for their own practice and the reflections that have helped them arrive at it (Helleve, 2014).

In addition to discussions about evidence, a low threshold, useful activity might be action research projects that involve teacher educators and their students. Action research entails "a systematic investigation into one's own practice with the aim of improving teaching and learning" (Ulvik \& Riese, 2016, p. 441). In action research, the teacher takes their own practice as a point of departure for investigating ways of improving and applies systematic research cycles over time to fine tune different aspects of one's practice. The whole process may then be documented in research publications that can be used in teacher education to scaffold understanding of research (Ulvik et al., 2018). Researching their own practice may be a way for teacher educators to stay abreast relevant research, and has the added bonus of being efficient in terms of benefits for both teaching (e.g. improved practice) and research (e.g. publications). By further requiring that preservice teachers engage in action research as a part of their education, teacher educators may be providing increased possibilities for their students to grasp the design and methods used in research projects, as well as interpretation of results, and a systematic approach to developing teaching practice in a researchinformed manner (Ulvik \& Riese, 2016).

Another important source of knowledge and wisdom in teacher education are the 'practice teachers' that act as mentors or supervisors for teacher education students when they are completing the practical part of their teacher education programme (Bråten \& Ferguson, 2015). Since practice teachers are likely to influence the teacher education 'ethos' or epistemic system, strong collaborations between these teachers and the teacher educators in colleges and universities are particularly important. Practice teachers should therefore have insight and knowledge of particular teacher education programmes and their con- 
tents so that they can help preservice teachers to identify theory and research-based knowledge in action and help diminish experiences of the theory-practice gap (Thorsen, 2019). The processes of identifying and articulating the sources of their knowledge may be difficult and unnatural for practice teachers. One way to address this might be collaboration between student teachers, teacher educators and practice teachers (Hendriks et al., 2021). For example, having them engage in collaborative discussions about selected classroom observations may help all three to bridge the possible chasm in the space between practice and theory and increase preservice teachers' competence in identifying and using relevant educational research (Hartmann et al., 2021).

\section{Teach research literacy, sourcing and epistemic beliefs}

Together, the articles in this special issue underline the importance of teaching about research literacy and sourcing, as well as beliefs about sources of teaching knowledge and reliable processes for knowing in teaching. In a bid to increase teachers' research literacy, teacher education in Norway has recently been extended from four years to a five-year master course, with the aim of providing teachers with insight in research methods and increasing future teachers' understanding of and ability to make use of relevant research. The programme culminates in the preparation of a research-based MA-thesis (Norwegian Ministry of Education and Research, 2014, implemented from 2017). Courses that specifically address how to engage with educational research may also be an option where longer teacher education preparation courses are not. However, comprehending and engaging with research are difficult tasks in interdisciplinary fields like education and teaching, and this is further complicated by disciplinary dissensus and competing schools of thought (Battersby, 2019). Yet, the nature of interdisciplinary scientific knowledge is such that teachers rarely develop expertise in every discipline relevant for their practice, and thus it seems important that their training includes the ability to judge what experts and sources they may safely rely upon to avoid false beliefs (Bromme \& Thomm, 2016).

Sourcing encompasses "a complex set of competencies that include attending to, representing, evaluating, and using features of information sources" (Braasch, Bråten \& McCrudden, 2018, p.4). Advances in information and digital technologies have propelled research on people's competency in attending to and using source information to prominence in educational psychology (Braasch et al., 2018). And while much existing research has focused on students' learning from multiple texts, the efforts of the authors in this issue show the importance of bringing together research on sourcing and teaching knowledge.
There is a growing body of research on how to teach students to critically evaluate sources of information (for an overview see Brante \& Strømsø, 2018). Common for interventions at the level of higher education are use of inquiry tasks in multiple documents settings, and use of software that provides prompts for students to pay attention to important source information (Brante \& Strømsø, 2018). For teachers, relevant source information may focus on expertise, integrity, and benevolence (i.e., epistemic trustworthiness, Hendriks, Kienhues \& Bromme, 2015), which requires teachers to learn to pay attention to author credentials (e.g., professor of education, experienced teacher), or publisher information (such as governing bodies versus publishers with commercial interests).

Further, in light of increased focus on the role of testimony as a source of knowledge, it is important to address questions about how teachers determine which sources of testimony are reliable (Greene, 2016). Hendriks and colleagues (2021) detail conflicting research findings as to how teachers view educational research in terms of usefulness, or practical value. A main contribution of this research is the nuancing and underlining of the importance of teachers' epistemic aims in relation to this question, which may help researchers to improve teachers' use of research evidence by helping them to formulate more adaptive epistemic aims. Zimmermann and MaywegPaus (2021) combine technological insight with literature on collaborative argumentation to detail ways of improving preservice teachers' sourcing as part of teacher education. In another recent study, Hartmann et al. (2021) proffered increasing teachers' multiple document literacy skills as a way forward, since teachers should be able to integrate and build on different sources of knowledge, and to be able to justify where this knowledge came from (see also Lunn Brownlee et al., 2017).

Using conflicting accounts of phenomena is one way of motivating students to reflect on their topic-specific beliefs about knowledge and processes of knowing (Ferguson et al., 2012). The different perspectives that are represented in most educational psychology textbooks provide authentic examples of how educational theory has changed over time, and how different sources of knowledge (here represented by different educational theorists) may provide different interpretations of similar behaviour. Coupled with this are conflicting educational theories (see Menz et al., 2021) where some have better-qualified justifications than others. This creates rife opportunities for students to reflect on their own beliefs about educational knowledge, as well as how this influences their teaching practice. Teacher educators might also scaffold small group discussions where preservice teachers articulate and reflect over their beliefs in terms of implications for practice and how these (actually) come to fruition, and 
practice teachers can guide these processes in action (Lunn Brownlee et al., 2017).

\section{The role of practice-informed educational research}

Since communication is not a one-way street, increasing teachers' research literacy and helping them develop sourcing strategies and beliefs that are more favourable to research-informed sources of teaching knowledge is necessary, but not sufficient. Equally important is the provision of empirical and theoretical educational research that is "easily accessible and comprehensively prepared for use by teachers" (Hendriks et al., 2021, p.25), or, "accessible, relevant, and applicable" (Van Schaik, Volman, Admiraal, \& Schenke, 2018, p.59).

The practice-theory gap is a well-known phenomenon in teaching and educational research (Bråten \& Ferguson, 2015; Hendriks et al., 2021), and is particularly salient in the discussion on evidence-based practice. Hendriks and colleagues (2021) provide a nuanced understanding of teachers' perceptions of educational experts, as well as the influence of epistemic aims on these perceptions, and Thomm and colleagues shed further light on barriers to accessing and using educational research, including time constraints and perceived sourcing skills, as well as the perceived failure of educational research to provide definitive results with clear implications (Thomm, Sälzer et al., 2021). Educational researchers have further been accused of conducting irrelevant, short-lived, and artificial experiments that fail to account for educational realities and contextual variations (Bubikova-Moan \& Opheim, 2021; Slavin, 2002; Van Schaik et al, 2018). Educational researchers are met with hurdles in terms of school cultures and the degree to which research consultation is supported by them (Greene, 2016), and teachers' perceptions of their ability to teach and interact with students, since teachers that are satisfied with their results might be more tempted to continue with business as usual (Thomm, Sälzer et al., 2021).

"Wisdom of practice" has long been a recognised source of teaching practice (Shulman, 1987), and recent attention to the merits of testimony in epistemic cognition (Chinn et al., 2011) underline the complex relation between different types of perceived expertise, as well as the important role of trust on behalf of the knowledge consumer (Hendriks et al., 2015), underlining the need for more investigations into sourcing in teaching like the ones in this special issue. Preservice teachers start off teacher education aiming to gather tips and applicable principles that they can use in the classroom (Hendriks et al., 2021). Researcher-teacher collaborations to identify research needs and document practices used by successful teachers (Shulman, 1987) could help to bridge practice and theory, as well as overcoming problems relating to more ad hoc application of advice from colleagues, based on small samples and lacking systematic review (Menz et al., 2021). Moreover, researchers should pay more attention to educational realities and how their research can be implemented in their research communication. One way in which educational researchers have already addressed this is by entering into research partnerships with schools, however these partnerships have to account for the added pressure that they place on already hectic schedules for teachers, as well as the juxtaposition between fidelity and teacher autonomy (Bubikova-Moan \& Opheim, 2021).

In addition to clarity about implications and limitations, educational researchers may need assistance from 'bridgers' and 'translators' (see Hofer, 2017) in the form of "trusted, impartial, educator-friendly reviews of research" (Slavin, 2002 p.125). Poorly communicated, or difficult to comprehend research not only leads to teachers reinforcing negative beliefs about educational research(ers) (Hendriks et al., 2021), but it leaves the door open to better communicated and more appealing, but less rigorous knowledge (Hendriks et al., 2021; Menz et al., 2021).

A number of initiatives, such as "What Works Clearing House" (Diery et al., 2020), Evidence for ESSA and BestEvidence Encyclopedia (Slavin, 2020) and The Institute of Educational Sciences (IES) (Basckin, Strnadova \& Cumming, 2021), have been established to gather quality educational research and provide summaries of individual papers, as well as overviews of large-scale initiatives. Further, research on evidence-based practice has evolved from simply identifying interventions, to studying manners of implementation and possible barriers (Basckin et al., 2021).

\section{Final remarks}

'Good teaching' does not come in bottles, and so the task of agreeing on the ingredients falls on teacher educators, practice teachers, educational researchers, policy makers, and, ultimately, teachers. Calls for evidence-informed practice tend to refer to increasing teachers' use of educational theory and research (Kvernbekk, 2016), but individual knowledge and best practices also serve teachers well (Shulman, 1987), and professional teachers will likely continue to depend on an assortment of sources of teaching knowledge with varying degrees of 'scientificness', for the foreseeable future. Teacher education and research each have roles to play in helping teachers develop competence and confidence in their ability to synthesize 'quality' educational resources. And further teasing apart of the role of 
testimonial evidence and teachers' judgements about which authorities to give precedence seem paramount.

The combined insights from the thoughtful papers in this special issue offer nuanced understandings and promising avenues for further research. While research findings from teachers' beliefs and epistemic cognition may not prove to be the panacea for the conundrum of evidence-informed teaching and teachers' sourcing behaviour, these are highly relevant, yet under-communicated areas of research that have much to offer teacher education. In conducting this research, educational researchers must pay attention to the multi-faceted nature of teaching practice, as well as prioritising clear and comprehensible research communication that also attends to issues of implementation.

Due to vast experience in classrooms before embarking upon explicit teacher training, preservice teachers enter teacher education with preconceptions about teaching that are likely to be somewhat central, and intertwined with other belief systems (Rokeach, 1968), this means that they will influence their understanding of and attitudes towards the different sources of knowledge they encounter in teacher education (Kiemer \& Kollar, 2021), as well as interactions with the students they meet in practice (Buehl \& Fives, 2016). Efforts to increase evidence-based practice might incorporate explicit training and opportunities for scaffolded practice in identifying and making use of educational research in teacher education class, as well as teacher educators that model, reflect on and share insights by documenting their own evidence-based practice. Deeply held beliefs may be influential and stubborn in equal parts, thus increased efforts in terms of collaborative reasoning about real teaching scenarios (Zimmermann \& Mayweg-Paus, 2021), and guided reflection are also promising avenues.

\section{References}

Alexander, P. A. (2017). Reflection and reflexivity in practice versus in theory: Challenges of conceptualization, complexity, and competence. Educational Psychologist, 52(4), 307 - 314, https:// doi.org/10.1080/00461520.2017.1350181

Basckin, C., Strnadova, I. \& Cumming, T. M. (in press). Teacher beliefs about evidence-based practice: A systematic review. International Journal of Educational Research, 106. https://doi.org/ 10.1016/j.ijer.2020.101727

Battersby, M. (2019). Appeals to authority: sources and experts. In J. A. Blair. (Ed.) Studies in critical thinking. (pp. $289-305)$. Open Mongraph Press. https://doi.org/10.22329/wsia.08.2019

Bendixen, L. D. \& Rule, D. C. (2004). An integrative approach to personal epistemology: A guiding model. Educational Psychologist, 39(1), 69 - 80. https://doi.org/10.1207/s15326985ep3901_7

Biesta, G. J. J. (2010). "Why 'what works' still won't work: From evidence-based education to value-based education. Studies in Philosophy and Education, 29, 491-503. https://doi.org/10. 1007/s11217-010-9191-x
Braasch, J. L. G., Bråten, I. \& McCrudden, M. T. (2018). Introduction to research on multiple sources use. In J. L. G. Braasch, I. Bråten \& M. T. McCrudden (Eds.). Handbook of multiple source use (pp. 1 -13). New York, NY: Routledge.

Brante, E. \& Strøms $\emptyset$, H. I. (2018). Sourcing in text comprehension: a review of intervention targeting sourcing skills. Educational Psychology Review, 30, 773 -799. https://doi.org/10.1007/s106 48-017-9421-7

Bromme, R. \& Thomm, E. (2016). Knowing who knows: Laypersons' capabilities to judge experts' pertinence for science topics. Cognitive Science, 40, 241 - 252. https://doi.org/10.1111/cogs.12252

Brownlee, J., Purdie, N. \& Boulton-Lewis, G. (2001). Changing epistemological beliefs in pre-service teacher education students. Teaching in Higher Education 6(2), 247-268. https://doi.org/ 10.1080/13562510120045221

Brownlee, J. Schraw, G. \& Berthelsen, D. (2011). Personal epistemology and teacher education. New York, NY: Routledge.

Bråten, I. \& Ferguson, L. E. (2015). Beliefs about sources of knowledge predict motivation for learning in teacher education. Teaching and Teacher Education, 50, 13-23. https://doi. org/10.1016/j.tate.2015.04.003

Bubikova-Moan, J. \& Opheim, V. (in press). 'It's a jigsaw puzzle and a challenge': Critical perspectives on the enactment of an RCT on small-group tuition in mathematics in Norwegian lower-elementary schools. Journal of Educational Policy. https://doi.org/ 10.1080/02680939.2020.1856931

Buehl, M. M. \& Beck, J. S. (2015). The relationship between teachers' beliefs and teachers' practice. In H. Fives \& M. G. Gill (Eds.). International handbook of research on teachers' beliefs (pp. 66 - 84). New York, NY: Routledge.

Buehl, M. M. \& Fives, H. (2009). Exploring teachers' beliefs about teaching knowledge: Where does it come from? Does it change? The Journal of Experimental Education, 77(4), 367 - 407. https:// doi.org/10.3200/JEXE.77.4.367-408

Buehl, M. M. \& Fives, H. (2016). The role of epistemic cognition in teacher learning and praxis. In J. A. Greene, W. A. Sandoval \& I. Bråten (Eds.), The handbook of epistemic cognition (pp. 247 - 264). New York, NY: Routledge.

Chinn, C. A. \& Brewer, W. F. (2000) Knowledge change in response to data in science, religion, and magic. In K. S. Rosengren, C. N. Jonson \& P. L. Harris (eds.). Imagining the impossible: Magical, scientific, and religious thinking in children (pp.334-371). New York, NY: Cambridge University Press.

Chinn, C. A., Buckland, L. A. \& Samarapungavan, A. (2011). Expanding the dimensions of epistemic cognition: Arguments from philosophy and psychology. Educational Psychologist, 46, 141 - 167. https://doi.org/10.1080/00461520.2011.587722

Chinn, C. A. \& Rinehart, R. W. (2016). Epistemic cognition and philosophy. Developing a new framework for epistemic cognition. In J. A. Greene, W. A. Sandoval \& I. Bråten (Eds.), The handbook of epistemic cognition (pp. 460 - 478). New York, NY: Routledge.

Csanadi, A., Kollar, I. \& Fischer, F. (in press). Pre-service teachers' evidence-based reasoning during pedagogical problem-solving: better together? European Journal of Psychology of Education. https://doi.org/10.1007/s10212-020-00467-4

de Bruyckere, P., Kirschner, P. A. \& Hulshof, C. D. (2015). Urban myths about learning and education. London, UK: Elsevier.

Diery, A., Vogel, F., Knogler, M. \& Seidel, T. (2020.) Evidence-based practice in higher education: Teacher educators' attitudes, challenges, and uses. Frontiers in Education, 5, 62. https://doi. org/10.3389/feduc. 2020.00062

European Commission. (2007). Towards more knowledge-based policy and practice in education and training. Retrieved from https://op.europa.eu/en/publication-detail/-/publi cation/962e3b89-c546-4680-ac84-777f8f10c590/languageen 
Ferguson, L. E., Bråten, I. \& Strøms $\varnothing$, H. I. (2012). Epistemic cognition when students read multiple documents containing conflicting scientific evidence: A think-aloud study. Learning and Instruction, 22(2), 103-120. https://doi.org/10.1016/j.learnin struc.2011.08.002

Ferguson, L. \& Lunn, J. (in press). Teacher beliefs and epistemologies. In Oxford Bibliographies in Education. A. Hynds (Ed.). Oxford University Press.

Feucht, F. C., Lunn Brownlee, J. \& Schraw, G. (2017). Moving beyond reflection: Reflexivity and epistemic cognition in teaching and teacher education. Educational Psychologist, 52(4), 234-241, https://doi.org/10.1080/00461520.2017.1350180

Fives, H. \& Gill, M. G. (Eds.) (2015). International handbook of research on teachers' beliefs. New York, NY: Routledge.

Gill, M. G., Ashton, P. T. \& Algina, J. (2004). Changing preservice teachers' epistemological beliefs in teaching and learning mathematics: An intervention study. Contemporary Educational Psychology, 29, 164 - 185. https://doi.org/10.1016/j.cedpsych.2004.01.003

Greene, J. A. (2016). Interacting epistemic systems within and beyond the classroom. In J. A. Greene, W. A. Sandoval \& I. Bråten (Eds.). Handbook of epistemic cognition (pp.265 - 277). New York, NY: Routledge.

Hartmann, U., Kindlinger, M. \& Trempler, K. (2021, online first). Integrating information from multiple texts relates to pre-service teachers' epistemic products for reflective teaching practice. Teaching \& Teacher Education, 97. https://doi.org/10.1016/j. tate.2020.103205

Helleve, I. (2014). Teaching about teaching is to reveal how to live with uncertainty. Reflective Practice, 15(5), 603-617. https:// doi.org/10.1080/14623943.2014.900027

Hendriks F., Kienhues D. \& Bromme, R. (2015). Measuring laypeople's trust in experts in a digital age: The Muenster epistemic trustworthiness inventory (METI). PLOS ONE 10(10): e0139309. https://doi.org/10.1371/journal.pone.0139309

Hendriks, F., Seifried, E. \& Menz, C. (2021). Unraveling the "smart but evil" stereotype: Pre-service teachers' evaluations of educational psychology researchers versus teachers as sources of information. Zeitschrift für Pädagogische Psychologie, 35(2 - 3), 157 - 171. https://doi.org/10.1024/1010-0652/a000300

Hofer, B. K. (2017). Shaping the epistemology of teacher practice through reflection and reflexivity. Educational Psychologist, 52(4), 299 - 306. https://doi.org/10.1080/00461520.2017.1355 247

Hofer, B. K. \& Pintrich, P. R. (1997). The development of epistemological theories: Beliefs about knowledge and knowing and their relation to learning. Review of Educational Research 67(1), 88 -140. https://doi.org/10.3102/00346543067001088

Kerwer, M. \& Rosman, T. (2020). Epistemic change and diverging information: How do prior epistemic beliefs affect the efficacy of short-term interventions? Learning and Individual Differences, 80,1 - 13. https://doi.org/10.1016/j.lindif.2020.101886

Kiemer, K. \& Kollar, I. (2021). Source selection and source use as a basis for evidence-informed teaching: Do pre-service teachers' beliefs regarding the utility of (non-) scientific information sources matter? Zeitschrift für Pädagogische Psychologie, 35(2-3), 127 - 141. https://doi.org/10.1024/1010-0652/a000302

Kienhues, D., Bromme, R. \& Stahl, E. (2008). Changing epistemological beliefs: the unexpected impact of a short-term intervention. British Journal of Educational Psychology, 78, 545e565. https://doi.org/10.1348/000709907X268589

Kuhn, D. (1999). A developmental model of critical thinking. Educational Researcher, 28(2), 16-46. https://doi.org/10.3102/0013 $189 \times 028002016$

Kvernbekk, T. (2016). Evidence-based practice in education. Functions of evidence and causal presuppositions. New York, NY: Routledge.
Lee, Y.- H. (in press). Scaffolding university students' epistemic cognition during multimodal multiple-document reading: The effects of the epistemic prompting and the automated reflection report. The Internet and Higher Education, 49. https://doi. org/10.1016/j.ineduc. 2020.100777

Lortie, D. 1975. Schoolteacher: A sociological study. London, UK: University of Chicago Press.

Lunn Brownlee, J., Ferguson, L. E. \& Ryan, M. (2017). Changing teachers' epistemic cognition: A new conceptual framework for epistemic reflexivity. Educational Psychologist, 52(4), 242 - 252. https://doi.org/10/1080/00461520.2017.1333430

Menz, C., Spinath, B. \& Seifried, E. (2021). Where do pre-service teachers' educational psychological misconceptions come from? The roles of anecdotal versus scientific evidence. Zeitschrift für Pädagogische Psychologie, 35(2-3), 143-156. https://doi.org/10.1024/1010-0652/a000299

Norwegian Ministry of Education and Research (2014). Promotion of the status and quality of teachers - joint effort for a modern school of knowledge. Retrieved from https://www.regjeringen. no/globalassets/upload/kd/vedlegg/planer/kd_strategiskole_ web.pdf

Olafson, L. \& Schraw, G. (2006). Teachers' beliefs and practices within and across domains. International Journal of Educational Research, 45, 71-84. https://doi.org/10.1016/j.ijer.2006.08.005

Parkinson, M. \& Maggioni, L. (2017). The potential of interventions to change preservice teachers' epistemological beliefs. In G. Schraw, J. Lunn Brownlee, L. Olafson \& M. Vander Veldt Brye (Eds.). Teachers' personal epistemologies: Evolving models for informing practice (pp.215-237). Charlotte, NC: Information Age Publishing.

Pawson, R. (2006). Evidence-based policy. A realist perspective. Los Angeles, CA: Sage.

Perry, W. G., Jr. (1970). Forms of intellectual and ethical development in the college years: A scheme. San Francisco, CA: JosseyBass Inc.

Rokeach, M. (1968). Beliefs, attitudes and values: A theory of organization and change. San Francisco, CA: Jossey-Bass Inc.

Schraw, G., Olafson, L. \& Vander Veldt, M. (2011). Fostering critical awareness of teachers' epistemological and ontological beliefs (pp.149 - 164). In J. Brownlee, G. Schraw \& D. Berthelsen (Eds). Personal epistemology and teacher education. New York, NY: Routledge.

Shulman, L. (1987). Knowledge and teaching: Foundations of the new reform. Harvard Educational Review, 57, 1 -21. https://doi. org/10.17763/haer.57.1.j463w79r56455411

Sinatra, G. M. \& Chinn, C. A. (2012). Thinking and reasoning in science: Promoting epistemic conceptual change. In Harris, K., McCormick, C. B., Sinatra, G. M. \& Sweller, J. (Eds.), Critical theories and models of learning and development relevant to learning and teaching (Vol. 1, pp. 257 - 282). Washington, DC: American Psychological Association. https://doi.org/10.1037/13275-011

Slavin, R. E. (2002). Evidence-based education policies: Transforming educational practice and research. Educational Researcher, 31(7), 15-21. https://doi.org/10.3102/0013189X03 1007015

Slavin, R. E. (2020). How evidence-based reform will transform research and practice in education. Educational Psychologist, 55(1), 21 - 31. https://doi.org/10.1080/00461520.2019.1611432

Snow, P. (2019). What does evidence-based practice mean in education in 2019? Nomansis, 8, 7 - 9. Retrieved from https://www. nomanis.com.au/single-post/what-does-evidence-basedpractice-mean-in-education-in-2019

Thomm, E., Sälzer, C., Prenzel, M. \& Bauer, J. (2021). Predictors of teachers' appreciation of evidence-based practice and research findings. Zeitschrift für Pädagogische Psychologie, 35(2-3), 173 - 184. https://doi.org/10.1024/1010-0652/a000301 
Thomm, E., Seifrid, E. \& Bauer, J. (2021). Informing professional practice: (Future) teachers' choice, use, and evaluation of (non-) scientific sources of educational topics [Editorial for the special section]. Zeitschrift für Pädagogische Psychologie, 35(2 - 3), 121 -126. https://doi.org/10.1024/1010-0652/a000309

Thorsen, K. E. (2019). Utvikling av faglig kompetanse i praksis [Development of professional competence in practice]. In K. E. Thorsen \& S. Michelet (Eds.). Teoretiske og praktiske kunnskaper i lærerkvalifisering: Sammenhenger og spenninger [Theoretical and practical knowledge in teacher qualification: Connections and tensions] (pp. 25 -38). Oslo: Universitetsforlaget.

Ulvik, M. \& Riese, H. (2016). Action research in pre-service teacher education - a never-ending story promoting professional development. Professional Development in Education, 42(3), 441 - 457. https://doi.org/10.1080/19415257.2014.1003089

Ulvik, M., Riese, H. \& Roness, D. (2018). Action research - connecting practice and theory. Educational Action Research, 26(2), 273 - 287. https://doi.org/10.1080/09650792.2017.1323657

Van Schaik, P., Volman, M., Admiraal, W. \& Schenke, W. (2018). Barriers and conditions for teachers' utilisation of academic knowledge. International Journal of Educational Research, 90, 50 - 63. https://doi.10.1016/j.ijer.2018.05.003

Zimmermann, M. \& Mayweg-Paus, E. (2021). The role of collaborative argumentation in future teachers' selection of online information. Zeitschrift für Pädagogische Psychologie, 35(2-3), 185 - 198. https://doi.org/10.1024/1010-0652/a000307

\section{History}

Received January 31, 2021

Accepted February 2, 2021

Published online April 27, 2021

\section{ORCID}

Leila Ferguson

(iD) https://orcid.org/0000-0001-9115-5662

\section{Leila E. Ferguson}

Kristiania University College

School of Health Sciences

Kirkegata 24-26

0153 Oslo

Norway

leila.ferguson@kristiania.no 